African Crop Science Journal by African Crop Science Society is licensed under a Creative Commons Attribution 3.0 Uganda License. Based on a work at www.ajol.info/ and www.bioline.org.br/cs DOI: http://dx.doi.org/10.4314/acsj.v26i3.2

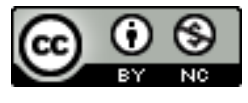

\title{
IDENTIFICATION OF A 'MILD' STRAIN OF Sweet potato chlorotic stunt virus AND IMPACT ON TITRES OF CO-INFECTING SPFMV
}

\author{
P. WASSWA, S.B. MUKASA and R.W. GIBSON ${ }^{1}$ \\ Department of Agricultural Production, Makerere University, P. O. Box 7062, Kampala, Uganda \\ ${ }^{1}$ Natural Resources Institute, University of Greenwich, Chatham Maritime, Kent, ME4 4TB, \\ United Kingdom \\ Corresponding author: wasswa@ caes.mak.ac.ug
}

(Received 2 January, 2018; accepted 30 July, 2018)

\begin{abstract}
The first indication of evolution in Sweet potato chlorotic stunt virus (SPCSV) was obtained when sweetpotato (Ipomoea batatas) plants of cv Kampala white from Busia district, eastern Uganda were shown to be infected with only SPCSV that induced mild symptoms in Ipomoea setosa. The objective of the study was to understand why the SPCSV isolate in Busia was not co-infected with SPFMV. 'Mild' SPCSV-infected plants were used to plant a field trial. The quantity of Sweet potato feathery mottle virus (SPFMV) was measured, using quantitative PCR (qPCR), in plants of I. setosa and cv Kampala white infected with SPFMV, 'mild' SPCSV + SPFMV or wild type SPCSV + SPFMV. The RNase3 and p22 genes of 'mild' SPCSV were sequenced and compared with those in the gene bank. qPCR assays were done to determine the titres of RNA1 (on to which RNase 3 and p22 are found) and RNA2. 'Mild' SPCSV reduced yield by up to $50 \%$. SPFMV titre was greatest in co-infections of SPFMV and wild type SPCSV; followed by co-infections of SPFMV and 'mild' SPCSV; and least in single SPFMV infections. The RNase3 of 'mild' SPCSV showed amino acid changes at position 34 (G to D) and 159 (H to Y), but p22 seemed normal. RNA1 was less expressed (though RNA2 continued to be 'normally' expressed) in the 'mild' SPCSV infection, than in the wild type SPCSV infection. This is the first example of a virus downgrading part of its genome to ensure that it alone benefits from RNA silencing suppression. The resulting improvement in its competiveness makes this strain likely to spread and become more important.
\end{abstract}

Key Words: p22, RNase3, SPCSV, sweetpotato

\section{RÉSUMÉ}

La première indication de l'évolution du virus stunt chlorotique de la patate douce (SPCSV) a été obtenue quand les plants de la patate douce blanche (Ipomoea batatas) du cv Kampala venue du district Busia, Est Ouganda ont été infectés avec seulement le SPCSV qui induit les symptômes 'mild' sur Ipomoea setosa. L'objectif de l'étude était de comprendre pourquoi l'isolat SPCSV en Busia n'était pas co-infecté avec SPFMV. Les plants infestés avec le 'mild' SPCSV ont été utilisés pour mettre en place un essai de champ. La quantité de virus spumeux de la tache de la patate douce (SPFMV) a été mesurée, en utilisant la PCR quantitative (qPCR), dans les plants de $I$. setosa et de cv Kampala blanc infectés avec SPFMV, 'mild' SPCSV + SPFMV ou le type sauvage de SPCSV + SPFMV. L'RNase3 et les gènes p22 du 'mild' SPCSV ont été séquencés et comparés à ceux de la banque de gènes. Les essais qPCR ont été faits pour déterminer les titrages du RNA1 (sur lequel RNase3 et p22 sont trouvés) et RNA2. Le 'Mild' SPCSV réduisent le rendement jusqu'à 50\%. Le titrage du SFMV était élevé en co-infections du SPFMV et du type sauvage du SPCSV ; suivi des co-infections de SPFMV et le 'mild' SPCSV ; et faible en infections simples du SPFMV. La RNase3 du 'mild' SPCSV a montré des changements en acide aminé à la 
position 34 (G à D) et 159 (H à Y), mais p22 a paru normal. Le RNA1 s'était moins exprimé (pourtant RNA2 a continué de s'exprimer normalement) dans l'infection du 'mild' SPCSV que dans l'infection du type sauvage du SPCSV. Ceci est le premier exemple d'un virus rétrogradant une partie du génome pour s'assurer les bénéfices de la suppression du RNA silencieux. L'amélioration résultant de sa compétitivité fait que cette souche probablement se répand et devient plus importante.

Mots Clés: p22, RNase3, SPCSV, patate douce

\section{INTRODUCTION}

Sweet potato chlorotic stunt virus (SPCSV) has a worldwide distribution and can be differentiated into the EA (East Africa) and WA (West Africa) strains. The EA group includes all isolates from East Africa and some from South America; whereas isolates from elsewhere in the World belong to the WA group (Alicai et al., 1999; Fenby et al., 2002; IsHak et al., 2003).

SPCSV by itself causes mild symptoms in sweetpotato and yield losses of up to $50 \%$ (Gibson et al., 1998; Mukasa et al., 2006). Likewise, plants infected with only SPFMV may have up to a $50 \%$ yield loss (Gibson et al., 1997; Njeru et al., 2004), but seldom show symptoms (Brunt et al., 1996; Kokkinos, 2006; Adikin et al., 2015). However, SPCSV synergises SPFMV to cause very severe symptoms of sweet potato virus disease (SPVD) (Gibson et al., 1998). SPVD can reduce the yield of affected plants by up to 98\% (Hanh, 1979; Ngeve and Bouwkamp, 1991; Gibson et al., 1998; Gutierrez et al., 2003).

The SPCSV genome is one of the largest of plant viruses (Kreuze et al., 2002), having up to 12 open reading frames (ORFs). It is bipartite, containing RNA1 (9407 nt) with five putative ORFs and RNA2 (8223 nt), with seven putative ORFs (Agranovsky et al., 1991; Cohen et al., 1992). In Uganda, there is a variant of SPCSV, which possesses RNase3 as well as p22 genes on RNA1 (Kreuze et al., 2002; Cuellar et al., 2008). The RNase3 gene, together with the p22 gene, break down the host plant's RNA silencing resistance (Kreuze et al., 2002, 2005). When SPFMV co-infects, it benefits from this destruction of the host's resistance, resulting in an increase of up to 600 fold in its titres (Mukasa et al., 2006); and causing the severe symptoms of SPVD (Karyeija et al., 2000; Gutierrez et al., 2003; Mukasa et al., 2006); while leaving SPCSV slightly reduced (Kokkinos and Clark, 2006). The objective of this study was to understand why the SPCSV isolate in Busia was not coinfected with SPFMV.

\section{MATERIALS AND METHODS}

Genesis of the study. In 2011, we collected 255 healthy sweetpotato cultivars from farmers' fields in Uganda as a potential source of farmer-preferred virus free elite cultivars. Plants were grown in pots in a screenhouse, at Makerere University Agricultural Research Institute (MUARIK) for 4 months before being tested for viruses. During this time, the netting of the screenhouse was torn (due to old age), exposing the plants to vectors for more than 3 months. These plants were then tested using NCM-ELISA kit originating from International Potato Centre (CIP), Peru. From this countrywide survey, only one plant of cv Kampala White from a field in Busia district had SPCSV alone. This scenario is very rare because SPCSV normally breaks down the resistance of sweetpotato plants to SPFMV, so plants become co-infected. Eighteen of the other plants were infected with SPFMV + SPCSV and 44 were infected with SPFMV alone (192 appeared to be virus free). This unusual SPCSV single infection caused only mild chlorosis symptoms in the indicator plant, $I$. setosa. These circumstances piloted the setting up of subsequent experiments, partly in case 'mild' SPCSV could cross protect and so provide means of controlling the wild type. 
This led eventually to a study of the mechanism behind the absence of co-infecting SPFMV with this 'mild' SPCSV.

Prevalence of SPFMV, SPCSV and SPVD in Busia district. A survey for SPFMV, SPCSV and SPVD prevalence was done in 2011 on five farms in Busia district in eastern Uganda, where the original 'mild' SPCSV was obtained. Plants were assessed by visually observing symptoms, because 'mild' SPCSV was observed to induce quite distinct purpling in infected sweetpotato plants. SPVD was also assessed visually because SPVD affected plants, in normal cases, showed severe symptoms, including mosaic or vein clearing on affected leaves. The distance between sampled fields was about $6 \mathrm{Km}$ and in each field, all mounds were closely inspected for disease symptoms, with each mound being an observational unit. The average size of each field was about $2000 \mathrm{~m}^{2}$ with on average 2000 mounds. Sample cuttings were collected and grown in a screenhouse at MUARIK. These were later grafted to I. setosa to check visual observations and to assess the prevalence of SPFMV single infections.

Incidences of SPFMV, SPCSV and SPVD were calculated as the percentage of the vines showing SPFMV, SPCSV or SPVD symptoms, out of the total number of vines assessed in a field. The total number of vines in a field was obtained by multiplying the number of mounds by 6 ; six was the number of vines that was observed to be planted in each mound in Busia district.

Single infection by 'mild' SPCSV. A cutting of cv Kampala White, infected with 'mild' SPCSV, was grown in a greenhouse at Food and Environment Research Agency (FERA), UK, and re-tested for SPFMV and SPCSV by grafting to one week old $I$. setosa seedlings, and using RT-qPCR. Observations for symptom development were made for a period of 4 weeks after graft inoculation. Total nucleic acid (TNA) was extracted from leaves of 'mild' SPCSV infected cv Kampala White and I. setosa using a modified CTAB method (Maruthi et al., 2002). The quality and quantity of RNA were determined using a NanoDrop ${ }^{\circledR}$ 2000 Spectrophotometer. All samples were then diluted to a concentration of $10 \mathrm{ng} \mathrm{ml}^{-1}$ before being used in the RT-qPCR amplifications for detection of SPCSV and SPFMV.

Degenerate SPCSV primers designed for the heat shock protein 70 (HSP70) region [EASPCSV-38F (5'-GGA GTT TAT TCC CAC CTG TYT ATC TG-3'), EA-SPCSV-126R (5'GGT AAT TGC GAA GAA TCYAAAACC-3') and the probe EA-SPCSV-67P* (5'-CGG CTA CAG GCG ACG TG-3')] were used. For SPFMV RT-qPCR, specific SPFMV primers designed using the CP region [SPFMV-Uni818F (5'-CGC ATA ATC GGT TGT TTG GTT T-3'), SPFMV-Uni-925R (5'-TTC CTA AGA GGT TAT GTA TAT TTC TAG TAA CAT CAG-3') and the probe SPFMV-Uni-847P * (5'-AAC GTC TCC ACG CAA GAA GAG GAT GC-3')] were used. The TaqMan probe method of RT-qPCR reaction was performed on Mastercycler ${ }^{\circledR}$ ep realplex Sequence Detection System using PCR microplates (twin.tec PCR plate 96, skirted) that were sealed with optical adhesive covers (Applied Biosystems).

The RT-qPCR was done in a $25 \mu \mathrm{l}$ reaction mixture. This contained $2.5 \mu \mathrm{l}$ of $10 \mathrm{X}$ buffer A, $5.5 \mu \mathrm{l}$ of $25 \mathrm{mM} \mathrm{MgCl}, 2 \mu \mathrm{l}$ of $2.5 \mathrm{mM}$ dNTP mix, $1.0 \mu \mathrm{l}$ of each primer $(7.5 \mathrm{p}$ mol $\left.\mu \mathrm{l}^{-1}\right), 0.5 \mu \mathrm{l}$ of TaqMan probe $\left(5 \mathrm{p} \mathrm{mol} \mathrm{Il}^{-1}\right)$, $0.05 \mu \mathrm{l}$ of RT (M-MuLV 200U $\left.\mu \mathrm{l}^{-1}\right), 0.125 \mu \mathrm{l}$ of AmpliTaq Gold polymerase $\left(5 \mathrm{U} \mathrm{\mu l}^{-1}\right)$ and 1 $\mu \mathrm{l}$ of template RNA. Finally, $11.325 \mu \mathrm{l}$ of molecular grade water were added to bring the volume to $25 \mu \mathrm{l}$. A negative control (molecular grade water), a positive control (RNA from SPVD affected sweetpotato plant) and a housekeeping gene [cytochrome oxidase (cox)] (Weller et al., 2000), were included on the plate and each sample was duplicated to reduce pipetting errors and to correct for differences in RNA concentrations between samples. RT-qPCR thermal cycler conditions used included $48{ }^{\circ} \mathrm{C}$ for 30 minutes (cDNA 
synthesis), $95{ }^{\circ} \mathrm{C}$ for 10 minutes (AmpliTaq Gold activation); followed by 40 cycles of denaturation at $95{ }^{\circ} \mathrm{C}$ for 15 seconds and annealing/extension at $60{ }^{\circ} \mathrm{C}$ for 60 seconds.

RNase3 and p22 of 'mild' SPCSV and wild type SPCSV strains. Total nucleic acid was extracted, using the modified CTAB method, from an SPVD affected plant of an unknown cultivar from Kampala; and the 'mild' SPCSVinfected cv Kampala White. cDNA was synthesized from $6 \mu \mathrm{l}$ of genomic RNA, in a $22.5 \mu \mathrm{l}$ reaction mixture using Superscript ${ }^{\mathrm{TM}}$

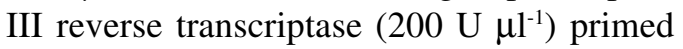
with random primers. Primer pairs, RNase $3 \mathrm{~F}$ (5'-TCG TCG TTT CGY AAG ATT TTC G3') and RNase3 R (5'-ARA CCA AAG TAG KGC CAC ATC AA-3'); and p22 F (5'-CTT TGA ACG ATG AGT TCT GG-3') and p22 R (5'-CTA CCC TAA TAT CTT TAT CG-3'), designed to anneal to specific regions of RNase 3 and $\mathrm{p} 22$ genes, respectively, were used for PCR amplification of the respective cDNA templates.

The $25 \mu$ RT-PCR reaction mixture for each gene consisted of $2.5 \mu \mathrm{l}$ of $10 \mathrm{X}$ reaction buffer, $0.5 \mu \mathrm{l}$ of $25 \mathrm{mM} \mathrm{MgCl}, 2.0 \mu \mathrm{l}$ of 10 $\mathrm{mM}$ dNTPs, $0.5 \mu \mathrm{l}$ of $20 \mathrm{mM}$ of each primer, $0.1 \mu \mathrm{l}$ of $2.5 \mathrm{U}$ of Taq DNA polymerase (Invitrogen) and $2.0 \mu \mathrm{l}$ of cDNA. Sterile water was added to bring to $25 \mu \mathrm{l}$ volume. cDNA was denatured at $94{ }^{\circ} \mathrm{C}$ for two minutes, 35 cycles of $94{ }^{\circ} \mathrm{C}$ for 30 seconds (denaturing), $52{ }^{\circ} \mathrm{C}$ (annealing) for 30 seconds, and $72{ }^{\circ} \mathrm{C}$ (extension) for 1 minute. The reaction was ended with a final extension step at $72{ }^{\circ} \mathrm{C}$ for 10 minutes.

Amplicons were separated on a $1 \%$ agarose gel containing $0.1 \mu \mathrm{l}$ of ethidium bromide per gramme of gel, in $1 \mathrm{X}$ Tris ethylene diamine tetra acetic acid (Tris-EDTA) buffer at 90 volts for 50 minutes; and then viewed under UV light. Comparison was made on RNase3 band size between 'mild' SPCSV and wild type SPCSV strains. PCR products of both RNase 3 and p22 of the 'mild' SPCSV strain were then separately cloned into pGEM-T Easy vectors
(PromegaUKLtd). Clones were checked for the correct length of insert before sequencing (GeneService London). Three independent clones were sequenced for each gene to ensure sequence identity and reliability. The sequences obtained were compared to other sequences of RNase 3 and p22 genes of SPCSV found in the GenBank (http://blast.ncbi.nlm.nih.gov), and in the literature (Tugume, 2010).

Spread of 'mild' SPCSV and effect on yield. Further, samples of 'mild' SPCSV-infected sweetpotato cv Kampala White were collected from Busia. These were grown in a screenhouse at MUARIK, and indexed for virus diseases using I. setosa. A total of 120 plants were found to have 'mild' SPCSV and none had SPFMV.

This material was multiplied and used to set up field trials in farmers' fields for season B of 2011. Trials were conducted in Busia district and at MUARIK; Busia was selected because the 'mild' SPCSV was originally identified from Busia; while MUARIK was used because it is a high disease pressure zone.

Each experiment comprised four plots of healthy plants, and four plots of 'mild' SPCSVinfected plants, arranged in a replicated randomised Latin square design. Each plot had four mounds, each approximately $1 \mathrm{~m}$ in diameter. Three cuttings were planted per mound. Whiteflies and aphids were counted in the fields on every four mounds, for a period of 5 minutes, and average number of whiteflies/aphids counted per 5 minutes calculated. The counting was done at 19 weeks after planting.

Observations were made at 25 weeks on the spread of SPVD and 'mild' SPCSV. Root yield was evaluated by taking the weight of saleable roots. The mean and Probability (P) values were generated by subjecting the yield data to ANOVA using GenStat 14.0 for Windows.

Effect of 'mild' SPCSV strain on SPFMV and on wild type SPCSV. A greenhouse 
experiment was done at Natural Resources Institute (NRI), UK where Cv Kampala White plants were separately graft inoculated with SPFMV alone, 'mild' SPCSV alone, SPFMV + 'mild' SPCSV, SPFMV + wild type SPCSV, and SPFMV + 'mild' SPCSV + wild type SPCSV. Symptom development was assessed for 9 weeks, and the oldest leaf was collected weekly from each of the plants, and stored at $-80{ }^{\circ} \mathrm{C}$. At the end of 9 weeks, shoot tips from five bottom-consecutive shoots along the main stem of each of the infected plants, were grafted to I. setosa and disease symptom development observed for 4 weeks. Healthy plants were also grafted to I. setosa to act as control.

The leaf samples collected were used for determining SPFMV and SPCSV titres, using RT-qPCR, with primer pairs based on the coat protein and HSP70 genes, respectively, as described above. RNase 3 and p22 titre in coinfections of SPFMV + 'mild' SPCSV, and SPFMV + wild type SPCSV, was also determined using RT-qPCR. SPFMV and SPCSV titre was determined using the TaqMan probe method described above. RNase 3 and p22 titres were determined using SYBR green method of RT-qPCR. Primer pairs for RNase3 [RNase3-F2 (5'-CCC GAC CAA ATG CAG TTG TG-3') and RNase3-R2 (5'-GCA CAA CCAACY AAC CAA CG-3')]; and p22 [p22F1 (5'-CCC TAA AAT CAC TAA TCG ATG AG-3') and p22-R1 (5'-AAA GAT GAG GAT GCA ATC GTT G-3')] were used.

The quality and quantity of RNA were determined using a NanoDrop ${ }^{\circledR} 2000$ Spectrophotometer. All samples were then diluted to a concentration of $10 \mathrm{ng} \mathrm{ml}^{-1}$ using, molecular grade water. The diluted samples were DNase treated prior to cDNA synthesis. The total reaction volume mixture of $10 \mu \mathrm{l}$ contained $4 \mu \mathrm{l}$ of sample, $1 \mu \mathrm{l}$ of RQ1 RNase free DNase, 10X reaction buffer, $1 \mu$ of RQ1 RNase free DNase and $4 \mu \mathrm{l}$ of molecular grade water. The mixture was incubated at $37{ }^{\circ} \mathrm{C}$ for 30 minutes. One $\mu \mathrm{l}$ of RQ1 DNase stop solution was then added to terminate the reaction.
The mixture was incubated at $65^{\circ} \mathrm{C}$ for 10 minutes to inactivate the DNase. cDNA was synthesized from $6 \mu$ of genomic RNA, in a $22.5 \mu \mathrm{l}$ reaction mixture, using Superscript ${ }^{\mathrm{TM}}$

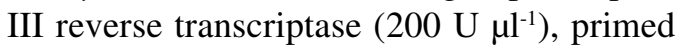
with random primers. The $25 \mu \mathrm{l} \mathrm{SYBR}$ green qPCR reaction mixture consisted of $12.5 \mu \mathrm{l}$ of SYBR, $8.5 \mu$ of molecular grade water, 0.75 $\mu \mathrm{l}$ of $5 \mathrm{mM}$ of each primer and $2.5 \mu \mathrm{l}$ of cDNA. A negative control (molecular grade water) and a housekeeping gene [cytochrome oxidase (cox)] (Weller et al., 2000), were included on the plate (twin.tec PCR plate 96, skirted). Each sample was duplicated to reduce pipetting errors.

Plates were sealed with optical adhesive covers (Applied Biosystems). The reaction was performed on Mastercycler ${ }^{\circledR}$ ep realplex Sequence Detection System. qPCR thermal cycler conditions used included $95{ }^{\circ} \mathrm{C}$ for 15 minutes (SYBR activation); followed by 40 cycles of denaturation at $94{ }^{\circ} \mathrm{C}$ for 15 seconds, annealing at $52{ }^{\circ} \mathrm{C}$ for 30 seconds and extension at $72{ }^{\circ} \mathrm{C}$ for 30 seconds.

Relative virus titre and gene expression data were analysed from the raw fluorescence data using the $2^{(-D e l t a \text { Delta } C(T))}$ method described by Livak and Schmittgen (2001).

\section{RESULTS}

\section{Prevalence of SPFMV, SPCSV and SPVD}

in Busia district. Cultivar Kampala White was the predominant cultivar grown in Busia district. This cultivar was found in fields at all the five farms visited (Table 1). Other cultivars grown included Bunduguza, Silk and Mubirigwambidi; and were either in separate fields or mixed with Kampala White. Although SPCSV symptoms were common, SPVD was rarely observed at any of the farms visited (Table 1). In confirmation, plant samples observed as having SPCSV or SPVD symptoms in the field reacted when grafted to I. setosa either by showing mild chlorosis for SPCSV or severe mosaic symptoms typical of plants with SPFMV + SPCSV infections. 
TABLE 1. Prevalence (by symptom observation and grafting samples to I. setosa) of SPFMV, SPCSV and SPVD (percentage in parenthesis) in sweetpotato cultivars grown in Busia district in Uganda

\begin{tabular}{|c|c|c|c|c|c|c|}
\hline \multirow[t]{2}{*}{ Farm no. } & \multirow[t]{2}{*}{ Cultivars grown } & \multirow{2}{*}{$\begin{array}{c}\text { Number of vines } \\
\text { sampled }\end{array}$} & \multicolumn{3}{|c|}{ Number of vines infected with: } & \multirow{2}{*}{$\begin{array}{l}\text { Number } \\
\text { of vines not } \\
\text { infected with } \\
\text { any of viruses } \\
\text { tested }\end{array}$} \\
\hline & & & SPCSV & SPFMV & $\begin{array}{l}\text { SPCSV + } \\
\text { SPFMV }\end{array}$ & \\
\hline \multirow[t]{3}{*}{1} & Kampala White & 3300 & $165(5)$ & $0(0)$ & $0(0)$ & $3135(95)$ \\
\hline & Bunduguza & 750 & $0(0)$ & $0(0)$ & $8(1)$ & 742 (99) \\
\hline & Silk & 450 & $0(0)$ & $0(0)$ & $0(0)$ & $450(100)$ \\
\hline \multirow[t]{3}{*}{2} & Kampala White & 2550 & $1260(49.4)$ & $0(0)$ & $3(0.12)$ & $1287(50.47)$ \\
\hline & Mubirigwambidi & 600 & $0(0)$ & $0(0)$ & $30(5)$ & $570(95)$ \\
\hline & Silk & 750 & $0(0)$ & $0(0)$ & $0(0)$ & $750(100)$ \\
\hline \multirow[t]{4}{*}{3} & Kampala White & 4350 & $216(5)$ & $0(0)$ & $0(0)$ & $4134(95)$ \\
\hline & Mubirigwambidi & 2100 & $48(2.3)$ & $0(0)$ & $0(0)$ & $2052(97.7)$ \\
\hline & Bunduguza & 1650 & $0(0)$ & $0(0)$ & $0(0)$ & $1650(100)$ \\
\hline & Silk & 360 & $0(0)$ & $0(0)$ & $0(0)$ & $360(100)$ \\
\hline 4 & Kampala White & 11700 & $1521(13)$ & $0(0)$ & $1(0.01)$ & 10178 (86.99) \\
\hline 5 & Kampala White & 10050 & $302(3)$ & $0(0)$ & $1(0.01)$ & 9747 (96.98) \\
\hline Total & & 38610 & $3512(9.1)$ & $0(0)$ & $43(0.1)$ & 35055 (90.8) \\
\hline
\end{tabular}

Values in parenthesis represent the percentage prevalence of SPFMV, SPCSV, and SPFMV + SPCSV combination in Busia District in Uganda

None of the plants sampled reacted as infected with SPFMV alone.

Cultivar Kampala White single infection by 'mild' SPCSV. The 'mild' isolate of SPCSV, when infecting alone, produced purpling and chlorosis of leaves and general stunting, typical of SPCSV (Fig. 1). This isolate induced milder chlorotic symptoms compared to the more severe chlorotic symptoms induced by the wild type SPCSV in I. setosa (Fig. 1). Both the infected $\mathrm{cv}$ Kampala White plant and graft inoculated $I$. setosa tested positive only for SPCSV using RT-qPCR with Ct values of 22.03 and 20.48, respectively.

RNase 3 and p22 genes. RT-PCR results revealed the same size band of RNase3 from SPVD affected and 'mild' SPCSV-infected sweetpotato plants (Fig. 2). Full sequence of RNase 3 of 'mild' SPCSV (accession No. HE575406) showed two amino acid (aa) changes at position 34 (G to D) and 159 ( $\mathrm{H}$ to $\mathrm{Y}$ ), compared to those of RNase 3 found in GenBank. p22 (accession No. HE575409) was also found in the 'mild' SPCSV and showed no change to other $\mathrm{p} 22$ sequences found in GenBank.

\section{Spread of 'mild' SPCSV and effect on yield.}

There was limited spread of SPCSV in the field (Table 2), with no spread of SPVD at Busia. Only six plants out of 48 plants became infected, despite having completely-infected neighbouring plots (Table 2). Whiteflies were few; only four whiteflies were counted per 5 minutes in the whole field at 19 weeks after planting. Similarly, only two aphids (apterae) were counted per 5 minutes. 


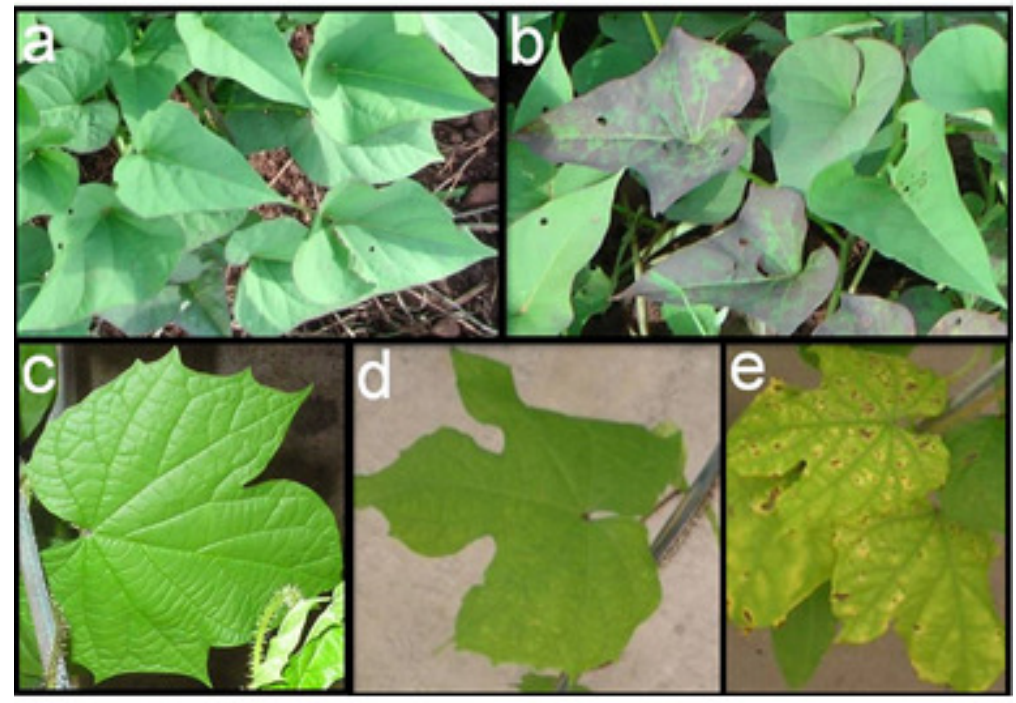

Figure 1. Mild SPCSV symptoms induced in I. setosa and purpling in sweetpotato plants: (a) Healthy field sweetpotato plants of cv Kampala White, (b) cv Kampala White infected with 'mild' SPCSV showing leaf purpling, (c) healthy I. setosa leaf (d) I. setosa leaf infected with 'mild' SPCSV showing mild chlorotic symptoms, and (e) I. setosa leaf infected with wild type SPCSV with severe chlorotic symptoms.

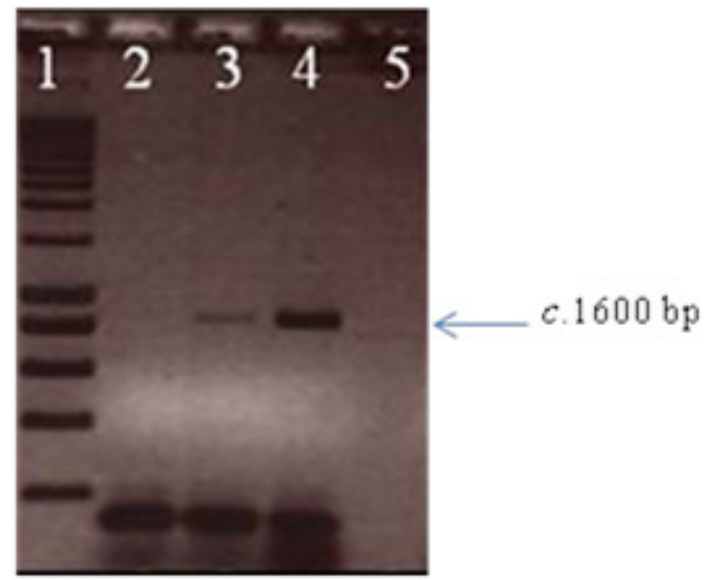

Figure 2. RT-PCR gel showing amplified products of RNase 3 of 'mild' and wild type SPCSV. Lanes: $1=1 \mathrm{~kb}$ ladder; 2 = Kampala White healthy, 3 = RNase 3 from wild type SPCSV, 4 = RNase 3 from 'mild' SPCSV, $5=$ Negative control (SDW).

TABLE 2. Spread of SPCSV in field trials of cv Kampala White in Busia and MUARIK in Uganda

\begin{tabular}{lcc}
\hline & $\begin{array}{l}\text { Busia } \\
\text { trial }\end{array}$ & $\begin{array}{c}\text { MUARIK } \\
\text { trial }\end{array}$ \\
\hline $\begin{array}{l}\text { Number of plants in originally healthy plots that became infected with SPCSV } \\
\text { Number of plants in originally healthy plants that became affected by SPVD }\end{array}$ & $3 / 48$ & $33 / 48$ \\
$\begin{array}{l}\text { Number of plants in originally 'mild' SPCSV-infected plants that became affected by } \\
\text { SPVD }\end{array}$ & $0 / 48$ & $7 / 48$ \\
\hline
\end{tabular}

MUARIK = Makerere University Agricultural Research Institute 
In the trial planted at MUARIK, SPCSV spread rapidly; 33 plants out of 48 plants on 16 mounds became infected with SPCSV (Table 2). Some of this spread was of wild type SPCSV because SPVD developed on some plants. Interestingly, SPVD was slightly more common and more severe on plants that were originally healthy than those that were originally infected with 'mild' SPCSV (Table 2). The whitefly population was high, with 225 whiteflies counted per 5 minutes when the field was 19 weeks old. Aphid population density was still low, but higher than in Busia; four aphids (apterae) counted per 5 minutes.

'Mild' SPCSV in Busia district reduced yield by over $50 \%$ (Table 3 ) with a significant effect of $\mathrm{P}<0.01$ (Table 4). In Busia, 'mild' SPCSV hardly spread to healthy plots. The difference was less evident (Table 3) and non-significant $(\mathrm{P}<0.05$; Table 4) at MUARIK, where many of the originally healthy plants also became infected with SPCSV or SPCSV + SPFMV;

TABLE 3. Storage root weight of 'mild' SPCSV-infected and healthy cv Kampala White in Busia and MUARIK in Uganda

\begin{tabular}{lcc}
\hline & \multicolumn{2}{c}{ Storage root weight $(\mathrm{kg})$ per hectare } \\
\cline { 2 - 3 } & Healthy & 'mild' SPCSV \\
\hline Busia & 520 & 226 \\
MUARIK & 253 & 173 \\
\hline
\end{tabular}

and a few of the originally 'mild' SPCSVinfected plants developed SPVD. 'Mild' SPCSV did not have any effect on root colour, texture or shape.

\section{Effect of 'mild' SPCSV strain on SPFMV} and on wild type SPCSV. Cultivar Kampala White plants graft-inoculated with co-infection of wild type SPCSV and SPFMV, developed typical SPVD (Fig. 3a); whereas Kampala White plants graft inoculated with 'mild' SPCSV and SPFMV had very mild or no symptoms (Fig. 3b). Results from the grafting of cv Kampala White to I. setosa, at the end of 9 weeks, showed reversion from SPFMV single infections in three out of five shoots. Reversion from SPFMV in co-infection of SPFMV + 'mild' SPCSV occurred in one out of five shoots; the shoot tip that showed reversion did not induce SPVD symptoms in $I$ setosa; but induced only development of mild leaf chlorosis. No reversion was observed in co-infection of SPFMV + wild type SPCSV (Table 5).

Ipomoea setosa plants graft-inoculated with shoots from SPFMV + 'mild' SPCSVinfected plants also showed less severe symptoms, plants continuing to grow (Fig. 4a). Ipomoea setosa plants graft-inoculated with shoots of plants co-infected with SPFMV + wild type SPCSV, were severely stunted and started dying from the top (Fig. 4b). It was also observed that sweetpotato graft inoculated

TABLE 4. ANOVA to test for differences in sweetpotato yield between symptomless and 'mild' SPCSVinfected cv Kampala White at MUARIK and Busia field trials in Uganda

\begin{tabular}{|c|c|c|c|}
\hline \multirow[t]{2}{*}{ Source of variation } & \multirow[t]{2}{*}{ d.f } & Mean squares & Mean squares \\
\hline & & Storage root yield at MUARIK & Storage root yield at Busia \\
\hline Replication & 3 & 0.833 & 12.138 \\
\hline Healthy status & 1 & $4.500^{\mathrm{ns}}$ & $61.605^{* *}$ \\
\hline Error & 3 & 3.667 & 1.338 \\
\hline Total & 7 & & \\
\hline
\end{tabular}

** indicates significance at $\mathrm{P}<0.01$. ${ }^{\mathrm{ns}}$ indicates non significance at $\mathrm{P}<0.05$ 


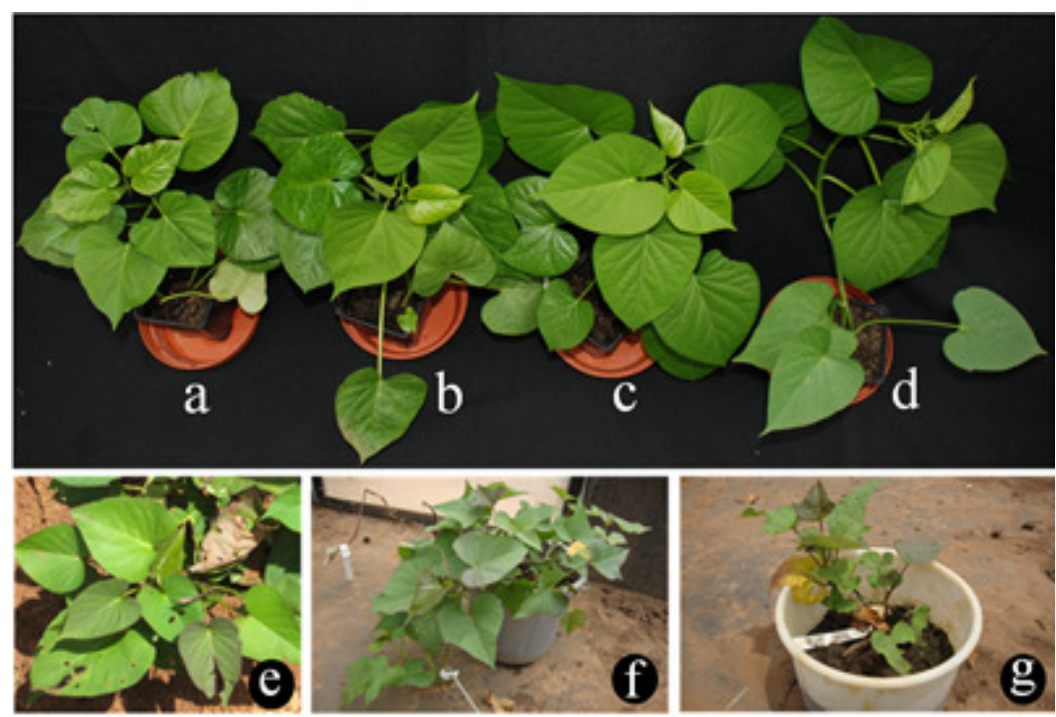

Figure 3. Cv Kampala White infected with different virus(es) showing differences in synergism between 'mild' SPCSV and wild type SPCSV when co-infect with SPFMV. a) co-infection of wild type SPCSV + SPFMV; b) coinfection of 'mild' SPCSV + SPFMV; c) SPFMV single infection; d) healthy plant; e) healthy field plant; f) plant graft inoculated with SPFMV + 'mild' SPCSV + wild type SPCSV; g) plant graft inoculated with SPFMV and wild type SPCSV. Pictures a to $\mathrm{d}$ were taken 8 weeks after graft inoculation while pictures $\mathrm{f}$ and $\mathrm{g}$ were taken 16 weeks after graft inoculation

TABLE 5. Reversion from SPFMV (as determined by grafting to I. setosa) in sweetpotato cv Kampala White infected with SPFMV alone, SPFMV + 'mild' SPCSV, and SPFMV + wild type SPCSV for 9 weeks

\begin{tabular}{lcccc}
\hline Shoot position & \multicolumn{4}{c}{ Cv Kampala White } \\
\cline { 2 - 5 } & Healthy & SPFMV & SPFMV + 'mild' SPCSV & SPFMV + wild type SPCSV \\
\hline 5 (most top) & - & - & - & + \\
4 & - & - & + & + \\
3 & - & - & + & + \\
2 & - & + & + & + \\
1 (most bottom) & - & + & + & + \\
\hline
\end{tabular}

+ and - indicate presence and absence of SPFMV symptoms, respectively

with wild type SPCSV + 'mild' SPCSV + SPFMV developed intermediary symptoms (Fig. 3).

With respect to virus titre, SPFMV titre was highest in Kampala White plants co-infected with wild type SPCSV + SPFMV; followed by plants co-infected with 'mild' SPCSV + SPFMV and least in plants singly infected with SPFMV (Table 6). Cv Kampala White singly infected with SPFMV started showing uneven virus distribution, 5 weeks after graft inoculation. By this time, SPFMV titre started reducing in co-infection of 'mild' SPCSV + SPFMV; however, it never reached zero for the period of 9 weeks, but did not reduce in co-infection of wild type SPCSV + SPFMV (Table 6).

SPCSV titre (using the HSP70 gene) of both 'mild' SPCSV single infection and in coinfection of 'mild' SPCSV + SPFMV was 


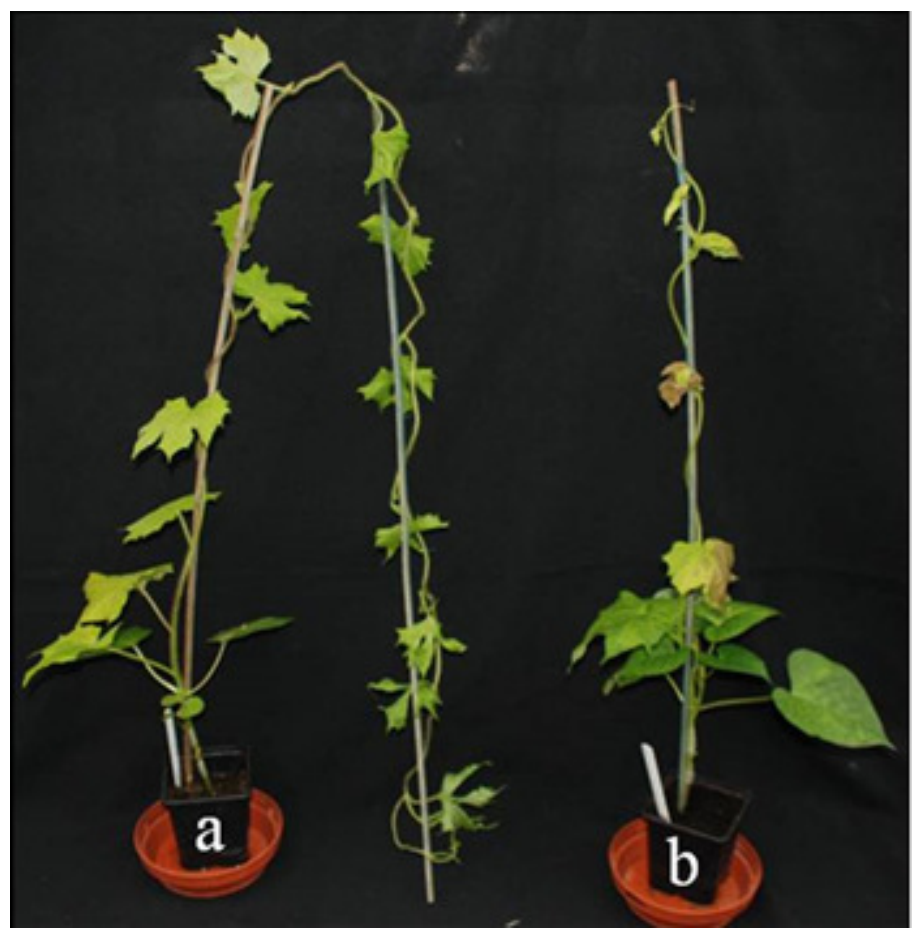

Figure 4. (a) I. setosa graft inoculated with SPFMV and 'mild' SPCSV and (b) I. setosa graft inoculated with SPFMV and wild type SPCSV showing differences in synergism between 'mild' SPCSV and wild type SPCSV.

TABLE 6. Mean fold change in SPFMV titre (average $2^{\wedge-\Delta \Delta C t}$ ) over time (weeks) in cv Kampala White plants infected with SPFMV, SPFMV + 'mild' SPCSV, and SPFMV + wild type SPCSV

\begin{tabular}{lrrr}
\hline Weeks & \multicolumn{3}{c}{ Average $2^{\wedge}-\Delta \Delta C \mathrm{C}$} \\
\cline { 2 - 4 } & SPFMV & SPFMV + 'mild' SPCSV & SPFMV + wild type SPCSV \\
\hline 1 & 1.095 & 252.55 & 4970.342 \\
2 & 1.708 & 103.121 & 2319.939 \\
3 & 1.012 & 115.099 & 7814.851 \\
4 & 1.001 & 532.382 & 3201.673 \\
5 & $(-)$ & 1.2151 & 230.089 \\
6 & 1.001 & 1.469 & 3898.812 \\
7 & $(-)$ & 1.045 & 822.033 \\
8 & 1.134 & 4.175 & 798.401 \\
9 & $(-)$ & 1.420 & 360.783 \\
\hline
\end{tabular}

(-) indicates negative sample

almost the same (Table 7), but it was 4.7 times less in co-infections of wild type SPCSV + SPFMV, compared to co-infections of 'mild' SPCSV + SPFMV (Table 8). RNase 3 and p22 genes were over 64 and 177 folds, respectively; greater in co-infection of wild type SPCSV + SPFMV compared to coinfection of 'mild' SPCSV + SPFMV (Table 8). 
TABLE 7. Mean fold change in HSP70 titre (average $2^{\wedge-\Delta \Delta C t}$ ) between single infection of 'mild' SPCSV and coinfection of 'mild' SPCSV + SPFMV in cv Kampala White plants at 9 weeks after graft inoculation

\begin{tabular}{lcc}
\hline Leaf position & \multicolumn{2}{c}{ Average $2^{\wedge-\Delta \Delta \mathrm{Ct}}$} \\
\cline { 2 - 3 } & 'mild' SPCSV infected plant & 'mild' SPCSV + SPFMV infected plant \\
\hline Bottom & 1.122 & 1.031 \\
Middle & 0.071 & 0.137 \\
Top & 0.667 & 0.68 \\
Mean of means & 0.620 & 0.616 \\
\hline
\end{tabular}

TABLE 8. Mean fold change in HSP70, RNase 3 and $\mathrm{p} 22$ titres (average $2^{\wedge-\Delta \Delta C t}$ ) over time (weeks) in cv Kampala White plants infected with SPFMV + 'mild' SPCSV, and SPFMV + wild type SPCSV

\begin{tabular}{|c|c|c|c|c|c|c|}
\hline \multirow[t]{3}{*}{ Weeks } & \multicolumn{6}{|c|}{ Average $2^{\wedge-\Delta \Delta C t}$} \\
\hline & \multicolumn{2}{|c|}{ HSP70 } & \multicolumn{2}{|c|}{ RNase3 } & \multicolumn{2}{|c|}{ p22 } \\
\hline & $\begin{array}{l}\text { SPFMV + } \\
\text { 'mild' } \\
\text { SPCSV }\end{array}$ & $\begin{array}{l}\text { SPFMV + } \\
\text { wild type } \\
\text { SPCSV }\end{array}$ & $\begin{array}{l}\text { SPFMV + } \\
\text { 'mild' } \\
\text { SPCSV }\end{array}$ & $\begin{array}{l}\text { SPFMV + } \\
\text { wild type } \\
\text { SPCSV }\end{array}$ & $\begin{array}{l}\text { SPFMV + } \\
\text { 'mild' } \\
\text { SPCSV }\end{array}$ & $\begin{array}{c}\text { SPFMV + } \\
\text { wild type } \\
\text { SPCSV }\end{array}$ \\
\hline 1 & 0.001 & 0.01 & 2.435 & 147.02 & 2.131 & 109.433 \\
\hline 2 & 0.0005 & 0.075 & 0.445 & 31.306 & 2.588 & 738.856 \\
\hline 3 & 0.00004 & 0.123 & 0.028 & 78.025 & 0.111 & 862.262 \\
\hline 4 & 0.01 & 0.014 & 0.179 & 3.156 & 1.295 & 126.359 \\
\hline 5 & 1.009 & 0.0005 & $(-)$ & 0.130 & $(-)$ & 1.331 \\
\hline 6 & 0.052 & 0.002 & 0.011 & 0.267 & $(-)$ & 3.83 \\
\hline 7 & 0.0001 & 0.004 & 0.042 & 2.156 & 1.913 & 261.235 \\
\hline 8 & 0.002 & 0.0005 & 0.023 & 1.238 & 0.123 & 64.504 \\
\hline 9 & 0.001 & 0.0003 & $(-)$ & 0.71 & $(-)$ & 2.545 \\
\hline Mean of means & 0.1195 & 0.025 & 0.452 & 29.334 & 1.360 & 241.151 \\
\hline
\end{tabular}

(-) indicates a negative sample

\section{DISCUSSION}

From the country-wide survey during this study, the only case of SPCSV single infection in sweetpotato was from Busia, the district where 'mild' SPCSV is prevalent. This is in agreement with results from previous surveys conducted before the identification of 'mild' SPCSV, where SPCSV rarely occurred by itself (Gibson et al., 1998). In Busia district, only a very few SPVD-affected plants (normally associated with SPFMV + wild type SPCSV) and no cases of SPFMV single infections were observed. Meanwhile, plants with symptoms of 'mild' SPCSV were common in the district (Table 1). Gibson et al. (1998) noted that cultivars can develop such mild SPVD symptoms that farmers cannot readily distinguish between affected and unaffected plants. Similarly, Alicai et al. (1999) used serology and identified isolates of SPCSV $_{\mathrm{EA}}$ differing in the severity of the 
associated SPVD. However, these previous reports involve relatively mild SPVD in farmers' fields.

Our report describes an absence of SPFMV and no (or a very few severe) SPVD in farmers' fields in Busia, and only getting mild SPVD in screenhouse experiment. The development of SPVD (though mild) in the screenhouse, yet is rare in Busia, is probably because of the stringent method of inoculation by grafting, as opposed to the natural means of inoculation in the field.

The availability of a 'mild' SPCSV strain suggests a possible opportunity for the control of SPCSV and so SPVD through cross protection. However, it appeared to cross protect only poorly and, although the 'mild' SPCSV strain caused no SPVD symptoms, it is not really mild in sweetpotato (even though it may be in I. setosa). It caused clear purpling and stunting of infected sweetpotato plants (Fig. 1), typical of wild type SPCSV infection (Duffus, 1995), including the SPCSV $\mathrm{EA}_{\mathrm{EA}}$ serotype (Gibson et al., 1998).

The virus also causes yield loss of up to $50 \%$ (Table 3), which is similar to yield losses observed by Gibson et al. (1998) and Mukasa et al. (2006), while working with the wild type SPCSV. Infection by 'mild' SPCSV did, however, cause seedlings of I. setosa to develop only mild chlorotic symptoms (Fig. 1). This is in contrast to observations made by Hoyer et al. (1996) working on SPCSV $\mathrm{EA}_{\text {, }}$ Gibson et al. (1998) working on $\mathrm{SPCSV}_{\mathrm{EA}}$ and Cohen et al. (1992) working on $\mathrm{SPCSV}_{\mathrm{WA}}$, who all noted stunting of $I$. setosa with small, brittle, and yellow leaves.

An isolate of SPCSV ${ }_{\mathrm{WA}}$ from Argentina caused mild mosaic symptoms in I. setosa, but unlike 'mild' SPCSV, this isolate caused mild mosaic in old and new leaves of sweetpotato. Co-infection of SPFMV and 'mild' SPCSV in sweetpotato plants in a screenhouse took abnormally long to produce SPVD symptoms; and even then symptoms were inconsistent and less severe than those that were observed when SPFMV co-infects with wild type SPCSV (Fig. 3). Furthermore, SPFMV titre was greatest in co-infections involving SPFMV and wild type SPCSV; followed by co-infections of SPFMV and 'mild' SPCSV and least in SPFMV single infections in both I. setosa and sweetpotato plants (Table 6).

Upon infection in normal situations, SPCSV breaks down the resistance of sweetpotato to virus through RNA silencing suppression (Kreuze et al., 2002; 2005). As a result, SPFMV easily infects such plants and multiplies to reach high titres (Mukasa et al., 2006), leading to the development of SPVD (Gibson et al., 1998). In bipartite criniviruses, the 3' proximal end of RNA1 contains the RNA silencing suppressor genes, RNase 3 and p22 (p22, is only reported in Ugandan SPCSV isolates) (Kreuze et al., 2002; 2005). SPCSV isolates that do not encode for p22 gene still successfully synergise heterologous viruses (Cuellar et al., 2008).

Kreuze et al. (2005) showed that the p22 gene somehow enhances silencing. Cuellar $e t$ al. (2008) found that most SPSCV do not possess a p22 gene (Ugandan SPCSV isolates are apparently exceptional), but that the synergy was greater when SPCSV encoding p22 co-infected with SPFMV than when a non p22 encoding SPCSV co-infected with SPFMV, confirming that the p22 gene, if present, confers some additive effect in synergism.

On the contrary, the 'mild' SPCSV strain encodes a p22 gene and one that is identical to the wild type SPCSV p22 genes in GenBank (Tugume, 2010), yet its synergistic effects are far less dramatic than wild type SPCSV. However, the 'mild' SPCSV RNase3 gene has two amino acid changes at position 34 ( $G$ to D) and 159 ( $\mathrm{H}$ to $\mathrm{Y})$, compared to those RNase 3 genes of wild type isolates found in the gene bank. Thus, this amino acid variation could explain the much less expression of the RNase 3 and p22 genes in the 'mild' SPCSV than in a wild type isolate, and thus the likely cause of this isolate's failure to synergise well 
SPFMV. This amino acid change could also suggest a reduction in the efficacy in any RNase 3 and $\mathrm{p} 22$ promoter gene(s) in the RNA1 region (RNA2 continues to occur 'normally' in 'mild' SPCSV as shown by the 'normal' expression of its HSP70 gene).

Experimentally, wild type and 'mild' SPCSV were also able to be made to co-exist together, and the outcome when infected also with SPFMV appears to be one of intermediate severity (Fig. 3). The mechanism responsible for RNA silencing suppression is the same as that for cross protection (Ratcliff et al., 1999; Kreuze et al., 2002); and it may be that the RNase 3 and p22 genes of SPCSV (of may be the wild type only), by hindering RNA silencing, allow more than one strain of the same virus to co-exist in the same plant, without dominance of one or the other.

SPVD was rarely observed in Busia district, though 'mild' SPCSV is prevalent, especially in the predominant cv Kampala White. There are several probable reasons that could be contributing to this SPVD rarity. Experimentally, SPFMV was observed not to be fully synergised by 'mild' SPCSV (Table 6). In addition, Kampala White plants were observed to have a dramatic decline in SPFMV titre (Table 6) from which they eventually reverted (Table 5). Previous studies have shown that aphids seldom acquire SPFMV, if the titres are as low as in singly infected plants (Aritua et al., 1998). Besides, aphids were few on sweetpotato in Busia district; though aphids are normally few in sweetpotato fields (Kantack et al., 1960; Aritua et al., 1998), and SPFMV is speculated to be transmitted by itinerant alate aphids of species that do not colonise sweetpotato. Because of the low virus titre and rarity of aphids, SPFMV may not be efficiently spread in fields in Busia district leading to less SPVD. It may also be due to the fact that cv Kampala White, the predominant cultivar in Busia, is relatively resistant to SPFMV as it was observed to revert from SPFMV single infections.

SPVD-affected plants remain very small and have pronounced symptoms for farmers to select against (Gibson et al., 2004). 'Mild' SPCSV singly infected sweetpotato plants manage to grow almost normally, so infected plants do not have a reduced visibility to whiteflies and farmers may find it difficult to select against such plants. In addition, in normal SPVD, wild type SPCSV titre is reduced (Karyeija et al., 2000; Kokkinos and Clark, 2006; Mukasa et al., 2006). This was indirectly confirmed in this study by two ways. Firstly, when the titre of the HSP70 gene (RNA2) of SPCSV was observed to be greater (4.7 fold) in co-infection of 'mild' SPCSV + SPFMV than in co-infection of wild type SPCSV + SPFMV (Table 8). This observation is consistent with results by Kokkinos and Clark (2006), where the titre of the wild type SPCSV was reduced in co-infections with SPFMV. Secondly, when the titre of SPCSV (HSP70) remained more-or-less the same both in single infection of 'mild' SPCSV and coinfection of 'mild' SPCSV + SPFMV (Table 7). Just like the case for aphids acquiring SPFMV, the unaffected titre of this 'mild' SPCSV in co-infections with SPFMV is likely to be more easily acquired by whiteflies than the lower wild type SPCSV titre in an SPVD affected plant. All these give advantage to 'mild' SPCSV and it may be expected that this poorly synergising strain of SPCSV will become much more widespread in Uganda. Indeed, it is already the prevalent isolate in Busia district.

\section{CONCLUSION}

Although 'mild' SPCSV causes less damage on an individual plant basis than the wild type which readily synergises SPFMV to cause SPVD, it could cause large losses in yield if it becomes more common than wild type SPCSV as a result of its apparent numerous survival advantages. The 'mild' strain is also an exciting example of a virus evolving to change its molecular behaviour so that it is no longer able to be 'parasitised' by other viruses 'piggy-backing' on its ability to combat RNA silencing by the host sweetpotato. Further studies of this 'mild' SPCSV will no doubt 
provide more detail of RNA silencing by plants and how viruses suppress it.

\section{ACKNOWLEDGEMENT}

The funding from Biotechnology and Biological Sciences Research Council (BBSRC) project BB/F004028/1 and all the contribution from NRI and MUARIK is highly appreciated.

\section{REFERENCES}

Adikini, S., Mukasa, S.B., Mwanga, R.O.M. and Gibson, R.W. 2015. Sweetpotato cultivar degeneration rate under high and low sweetpotato virus disease pressure zones in Uganda. Canadian Journal of Plant Pathology 37:136 - 147.

Agranovsky, A.A., Boyko, V.P., Karasev, A.V., Lunina, N.A., Koonin, E.V. and Dolja, V.V. 1991. Nucleotide sequence of the 3'terminal half of beet yellows closterovirus RNA genome: Unique arrangement of eight virus genes. Journal of General Virology 72:15 - 23.

Alicai, T., Fenby, N.S., Gibson, R.W., Adipala, E. Vetten, H.F., Foster, G.D. and Seal, S.E. 1999. Occurrence of two serotypes of Sweet potato chlorotic stunt virus in East Africa and their associated differences in coat protein and HSP70 homologue gene sequences. Plant Pathology 48:718 - 726.

Aritua, V., Alicai, T., Adipala, E., Carey, E.E. and Gibson, R.W. 1998. Aspects of resistance to sweetpotato virus disease in sweetpotato. Annals of Applied Biology 132:387 - 398.

Brunt, A.A., Crabtree, K., Dallwitz, M.J., Gibbs, A.J. and Watson, L. 1996. Viruses of plants: Descriptions and lists from the VIDE Database. CAB International 1484 pp.

Cohen, J., Franck, A., Vetten, H.J., Lesemann, D.E. and Loebenstein, G. 1992. Purification and properties of closterovirus-like particles associated with a whitefly- transmitted disease of sweetpotato. Annals of Applied Biology 121:257 - 268.

Cuellar, J.W., Tairo, F., Kreuze, J.F. and Valkonen, J.P.T. 2008. Analysis of gene content in Sweet potato chlorotic stunt virus RNA1 reveals the presence of the $\mathrm{p} 22$ RNA silencing suppressor in only a few isolates: Implications for viral evolution and synergism. Journal of General Virology 89: 573 - 582.

Duffus, J.E. 1995. Whitefly-borne viruses. In Bemisia. Intercept Ltd., Andover, UK (702pp): Chapter 24. pp. 255 - 263.

Fenby, N.S., Foster, G.D., Gibson, R.W. and Seal, S.E. 2002. Partial sequence of HSP70 homologue gene shows diversity between West African and East African isolates of Sweet potato chlorotic stunt virus. Tropical Agriculture 79:26 - 30.

Gibson, R.W., Aritua, V., Byamukama, E., Mpembe, I. and Kayongo, J. 2004. Control strategies for sweet potato virus disease in Africa. Virus Research 100:115 - 122.

Gibson, R.W., Mpembe, I., Alicai, T., Carey, E.E., Mwanga, R.O.M., Seal, S.E. and Vetten, H.J. 1998. Symptoms, aetiology and serological analysis of sweetpotato virus disease in Uganda. Plant Pathology 47:95 - 102.

Gibson, R.W., Mwanga, R.O.M., Kasule, S., Mpembe, I. and Carey, E.E. 1997. Apparent absence of viruses in most symptomless field grown potato in Uganda. Annals of Applied Biology 130:481 - 490.

Gutierrez, D.L., Fuentes, S. and Salazar, L.F. 2003. Sweet potato virus disease (SPVD): Distribution, incidence, and effect on sweetpotato yield in Peru. Plant Disease 87:297 - 302.

Hanh, S.K. 1979. Effects of viruses (SPVD) on growth and yield of sweetpotato. Experimental Agriculture 15:253 - 256.

Hoyer, U., Maiss, E., Jelkmann, W., Lesemann, D.E. and Vetten, H.J. 1996. Identification of the coat protein gene of a sweet potato sunken vein closterovirus 
isolate from Kenya and evidence for a serological relationship among geographically diverse closterovirus isolates from sweetpotato. Phytopathology 86:744 - 750.

IsHak, J.A., Kreuze, J.F., Johansson, A., Mukasa, S.B., Tairo, F., Abo El-Abbas, F.M. and Valkonen, J.P.T. 2003. Some molecular characteristics of three viruses in sweet potato virus disease-affected sweetpotato plants in Egypt. Archives of Virology 148: 2449 - 2460.

Kantack, E.J., Martin, W.J. and Newsom, L.D. 1960. Transmission of internal cork of sweetpotato by the cotton aphid, Aphis gossypii Glover. Science 127:3312.

Karyeija, R.F., Kreuze, J.F., Gibson, R.W. and Valkonen, J.P.T. 2000. Synergistic interactions of a potyvirus and a phloem limited crinivirus in sweetpotato plants. Virology 269:26 - 36.

Kokkinos, C.D. 2006. Assessment of interactions among viruses infecting sweetpotato. Doctoral Dissertation. Louisiana State University, Baton Rouge, USA. $134 \mathrm{pp}$.

Kokkinos, C.D. and Clark, C.A. 2006. Realtime PCR assays for detection and quantification of sweetpotato viruses. Plant Disease 90:783 - 788 .

Kreuze, J.F. 2002. Molecular studies on the sweet potato virus disease and its two causal agents. Doctoral dissertation. Swedish University Agricultural Sciences, Uppsala, Sweden. 63pp.

Kreuze, J.F., Savenkov, E.I., Cuellar, W., Li, X. and Valkonen, J.P.T. 2005. Viral class 1 RNase III involved in suppression of RNA silencing. Journal of Virology 79:7227 7238.

Livak, K.J. and Schmittgen, T.D. 2001. Analysis of relative gene expression data using real-time quantitative PCR and the 2 (Delta Delta $\mathrm{C}(\mathrm{T})$ ) method. Methods 25: $402-408$.

Maruthi, M.N., Colvin, J., Seal, S., Gibson, G. and Cooper, J. 2002. Co-adaptation between cassava mosaic geminiviruses and their local vector populations. Virus Research 86:71 - 85.

Mukasa, S.B., Rubaihayo, P.R. and Valkonen, J.T.P. 2006. Interactions between a crinivirus, an ipomovirus and a potyvirus in co-infected sweetpotato plants. Plant Pathology 55:458 - 467.

Ngeve, J.M. and Bouwkamp, J.C. 1991. Effects of sweet potato virus disease (SPVD) on the yield of sweetpotato genotypes in Cameroon. Experimental Agriculture 27:221 - 225.

Njeru, R.W., Mburu, M.W.K., Cheramgoi, E.C., Gibson, R.W., Kiburi, Z.M., Obudho, E. and Yobera, D. 2004. Studies on the physiological effects of viruses on sweetpotato yield in Kenya. Annals of Applied Biology 145:71 - 76.

Ratcliff, F.G., MacFarlane, S.A. and Baulcombe, D.C. 1999. Gene silencing without DNA: RNA-mediated crossprotection between viruses. Plant Cell 11: $1207-1216$.

Tugume, K.A. 2010. The significance of wild plants in the evolutionary ecology of three major viruses infecting cultivated sweetpotato in Uganda. Doctoral dissertation. Swedish University of Agricultural Sciences, Uppsala, Sweden.

Weller, S., Elphinstone, J., Smith, N., Boonham, N. and Stead, D. 2000. Detection of Ralstonia solanacearum strains with a quantitative, multiplex, realtime, fluorogenic PCR (TaqMan) assay. Applied and Environmental Microbiology 66:2853 - 2858. 